\title{
Central Regulation of Metabolism by Growth Hormone
}

\author{
Jose Donato Jr. ${ }^{1, *(\mathbb{C}}$, Frederick Wasinski ${ }^{1}$, Isadora C. Furigo ${ }^{1}$, Martin Metzger ${ }^{1}\left(\mathbb{D}\right.$ and Renata Frazão ${ }^{2}$ (D) \\ 1 Departamento de Fisiologia e Biofisica, Instituto de Ciencias Biomedicas, Universidade de Sao Paulo, \\ Sao Paulo 05508-000, Brazil; frednefro@gmail.com (F.W.); doraclivatti@gmail.com (I.C.F.); \\ metzger@icb.usp.br (M.M.) \\ 2 Departamento de Anatomia, Instituto de Ciencias Biomedicas, Universidade de Sao Paulo, \\ Sao Paulo 05508-900, Brazil; rfrazao@usp.br \\ * Correspondence: jdonato@icb.usp.br; Tel.: +55-1130910929
}

Citation: Donato, J., Jr.; Wasinski, F.; Furigo, I.C.; Metzger, M.; Frazão, R. Central Regulation of Metabolism by Growth Hormone. Cells 2021, 10, 129 https://doi.org/10.3390/cells100101 29

Received: 11 December 2020 Accepted: 5 January 2021 Published: 11 January 2021

Publisher's Note: MDPI stays neutral with regard to jurisdictional clai$\mathrm{ms}$ in published maps and institutional affiliations.

Copyright: (C) 2021 by the authors. Licensee MDPI, Basel, Switzerland. This article is an open access article distributed under the terms and conditions of the Creative Commons Attribution (CC BY) license (https:// creativecommons.org/licenses/by/ $4.0 /)$.

\begin{abstract}
Growth hormone (GH) is secreted by the pituitary gland, and in addition to its classical functions of regulating height, protein synthesis, tissue growth, and cell proliferation, GH exerts profound effects on metabolism. In this regard, GH stimulates lipolysis in white adipose tissue and antagonizes insulin's effects on glycemic control. During the last decade, a wide distribution of GHresponsive neurons were identified in numerous brain areas, especially in hypothalamic nuclei, that control metabolism. The specific role of GH action in different neuronal populations is now starting to be uncovered, and so far, it indicates that the brain is an important target of GH for the regulation of food intake, energy expenditure, and glycemia and neuroendocrine changes, particularly in response to different forms of metabolic stress such as glucoprivation, food restriction, and physical exercise. The objective of the present review is to summarize the current knowledge about the potential role of $\mathrm{GH}$ action in the brain for the regulation of different metabolic aspects. The findings gathered here allow us to suggest that GH represents a hormonal factor that conveys homeostatic information to the brain to produce metabolic adjustments in order to promote energy homeostasis.
\end{abstract}

Keywords: cytokines; energy balance; GH; glucose homeostasis; hypothalamus

\section{Introduction}

Growth hormone (GH) is a single-chain 191 amino acid protein (its major isoform) which is mostly secreted by somatotropic cells located in the anterior pituitary gland. GH presents a pulsatile secretion pattern that is controlled by hypophysiotropic hypothalamic neurons (Figure 1). The classical neuroendocrine neurons that regulate the pulsatile secretion of GH express either somatostatin (SST) or GH-releasing hormone (GHRH) [1,2]. While SST-expressing neurons inhibit GH secretion, GHRH stimulates GH synthesis and release (Figure 1). Accordingly, defects in GHRH signaling causes dwarfism due to impaired GH secretion [3]. Ghrelin (a GH-releasing peptide) is also a powerful endogenous GH secretagogue [4-7]. Ghrelin activates growth hormone secretagogue receptor (GHS-R) in the hypothalamus and pituitary to induce GH secretion [8,9].

The half-life of GH in the blood is short, which is evident from its pulsatile secretion pattern, but GH's pulsatile secretion pattern is the most important regulator of circulating insulin-like growth factor 1 (IGF-1), whose bioavailability is more stable [10] due to the fact that most of the circulating IGF-1 is associated with IGF-1 binding proteins. The liver is mainly responsible for maintaining circulating IGF-1 levels (Figure 1). Thus, the activation of GH receptor (GHR) in hepatocytes stimulates IGF-1 synthesis and secretion as well as increasing serum concentrations of this hormone [11,12]. The GH-IGF-1 axis is critically involved in the control of growth (Figure 1). However, genetic ablation of GHR from the liver does not compromise body growth as much as that caused by GHR deletion in the entire body, despite a drastic reduction in circulating IGF-1 levels [13]. Therefore, somatic growth is also directly regulated by GHR signaling in different tissues and local IGF-1 synthesis $[11,12,14]$. 


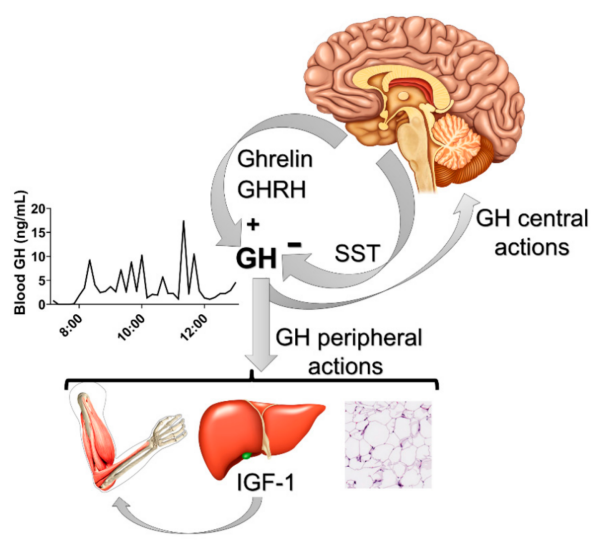

Figure 1. Neuroendocrine factors that control the pulsatile secretion of growth hormone (GH). Ghrelin and GH-releasing hormone (GHRH) stimulate pituitary GH secretion, whereas somatostatin (SST) inhibits it. The example of the pulsatile secretion of GH was obtained from a C57BL/6 eightweek-old male mouse after 36 serial blood collections in a 10-min interval (lights on at 7 am; 12-h light/dark cycle). Note that GH has central and peripheral actions (e.g., on the liver, muscle and white adipose tissue), in which the stimulation of insulin-like growth factor 1 (IGF-1) secretion from the liver plays a major role controlling somatic growth.

The strong relationship between circulating levels of GH and IGF-1 confounds the determination of the specific effects induced by each hormone individually, especially when considering the widespread expression of their receptors. However, with the generation of tissue-specific GHR- or IGF-1 receptor (IGF-1R)-deficient mice, the precise physiological role of each of these receptors in different tissues has been described [14-16]. In this regard, numerous studies produced tissue-specific knockout mice by deleting either GHR or IGF$1 \mathrm{R}$ from the bone, liver, adipose tissue, muscle, pancreatic $\beta$-cell and other organs [14-16]. Nevertheless, the distinct role of GHR signaling in the nervous system through the generation of brain-specific knockout mice has not been studied until recently [17].

In addition to its classical functions of regulating height, protein synthesis, tissue growth and cell proliferation, GH exerts profound effects on metabolism. Thus, GH stimulates lipolysis in white adipose tissue and antagonizes insulin effects on glycemic control [18-21]. Accordingly, GHR-deficient mice exhibit higher insulin sensitivity despite presenting increased percentages of body fat $[13,15,16,21]$. Since the classical target tissues of GH, including the liver, adipose tissue and muscle (Figure 1), are directly involved in the regulation of lipid and glucose metabolism, it is commonly assumed that the metabolic effects of GH are mediated by these organs. However, nowadays, it is well-established that the brain plays an important role regulating numerous metabolic aspects [22]. For example, target deletions of insulin or leptin receptors in the brain produce profound metabolic imbalances [23-25]. The brain is able to regulate systemic metabolism via the sympathetic and parasympathetic nervous systems. In addition, hypothalamic control of pituitary hormones, including those of the thyroid and adrenal axes, indirectly modulates whole-body metabolism [26,27]. In this present review, the current knowledge about the potential role of GH action in the brain for the regulation of different metabolic aspects is summarized, with a special focus on studies produced by our research group.

\section{GH Action in the Brain}

It has long been known that GHR is expressed in the brain [28,29]. Initially, GHR expression was described in hypothalamic areas that contain hypophysiotropic neurons that regulate pituitary GH secretion. In this context, previous studies have shown that a large percentage of SST neurons in the paraventricular $(\mathrm{PVH})$ and periventricular $(\mathrm{PV})$ hypothalamic nuclei express Ghr mRNA [28]. This finding is in accordance with the role of hypothalamic neurons regulating pituitary $\mathrm{GH}$ secretion via short negative feedback loops $[1,30]$. GHR is also amply expressed in the arcuate nucleus (ARH), which is the 
principal hypothalamic region that hosts GHRH-expressing neurons [28,31]. However, only a small percentage of GHRH neurons seem to contain GHR [32,33], whereas Ghr mRNA is abundantly detected in ARH neurons that express neuropeptide Y (NPY) [34,35]. Our research group has used the capacity of an acute GH injection to induce phosphorylation of the signal transducer and activator of transcription-5 (pSTAT5) as an alternative method to identify GH-responsive neurons [36,37]. Using this approach, the presence of GHresponsive neurons in the $\mathrm{ARH}, \mathrm{PVH}$ and $\mathrm{PV}$ was confirmed. Furthermore, numerous additional brain areas that are directly responsive to GH were identified [36,37]. Thus, the widespread distribution of GH-responsive neurons in the brain suggests that a broad array of neural functions can be modulated by the direct action of GH [38] (Figure 2).

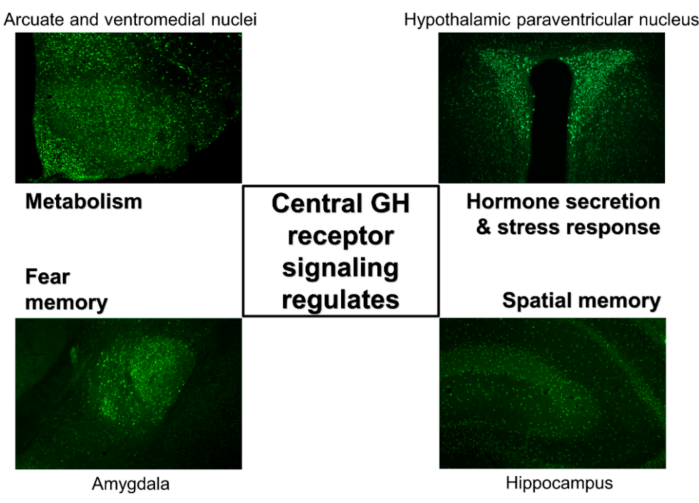

Figure 2. GH-responsive neurons are found in several brain structures, and GH receptor signaling regulates different neurological aspects. Coronal photomicrographs of different parts of the mouse brain showing immunoreactivity against the phosphorylation of the signal transducer and activator of transcription 5 after an acute GH injection. Previous studies indicated that GH receptor signaling in different brain areas regulates distinct physiological parameters. Although GH-responsive neurons are abundantly found in the paraventricular nucleus of the hypothalamus, the exact role played by $\mathrm{GH}$ in these cells is still unknown.

\section{Distribution of GH-Responsive Neurons in Mouse and Rat Brains}

Systemically or centrally injected GH induces phosphorylation of the signal transducer and activator of transcription 5 (pSTAT5) in several brain areas of rats and mice [36,37] (Figure 2). GH-induced pSTAT5 was detected only in neurons [36], although it is possible that other cell types such as epithelial or glial cells are also responsive to GH. GH-induced pSTAT5 cells were found in the lateral septum, bed nucleus of the stria terminalis (BNST), paraventricular nucleus of the thalamus, amygdala (mostly in the medial and central subdivisions) and dorsal raphe nucleus, which are brain structures involved in the regulation of behaviors, emotions, limbic information and valence monitoring. In line with the anatomical distribution of GH-responsive cells, previous studies have described a ghrelin-GH axis in the amygdala that controls fear memory formation (Figure 2), possibly contributing with excessive fear memory typical of post-traumatic stress disorder [39,40].

GH administration also leads to several pSTAT5-positive cells in the hippocampus, a key brain structure for memory formation [36,37] (Figure 2). GH replacement improves memory function in adults with childhood-onset GH deficiency [41,42]. Accordingly, GH modulates excitatory synaptic transmission in the hippocampus [43-45]. Interestingly, brain-specific Stat5a/Stat5b knockout mice exhibit memory deficits [46], suggesting that STAT5 is a downstream signaling pathway potentially recruited by GHR to modulate memory. Paradoxically, global GHR knockout mice are protected from age-related decline in memory retention $[47,48]$. Additionally, GH overexpression leads to poor spatial learning and memory, whereas transgenic expression of a GHR antagonist caused improved learning in twelve-month-old male mice [49]. These apparent contradictory results can be explained by the fact that GHR signaling regulates insulin sensitivity and there is plenty of evidence indicating that brain insulin action plays a major role in regulating memory 
and is likely involved in the pathophysiology of Alzheimer's disease [50-52]. Since global GHR knockout mice and GHR antagonist transgenic mice exhibit improved insulin sensitivity, whereas GH overexpression causes insulin resistance [21,53], the changes in memory performance in these mouse models are probably related to alterations in insulin action rather than a direct role of GHR signaling in the hippocampus.

Among all brain regions that express GHR, the hypothalamus displays the highest density of neurons responsive to GH [36,37]. Of note, GH-responsive neurons are particularly abundant in hypothalamic areas considered key players in the control of metabolism, including the ARH, PVH, ventromedial nucleus (VMH), dorsomedial nucleus (DMH) and lateral hypothalamic areas. Thus, GH action on these hypothalamic centers strongly indicates that the central regulation of energy and glucose homeostasis can be modulated by GHR signaling (Figure 2).

\section{Central Regulation of Metabolism by GH}

\subsection{GH Regulates Food Intake}

Findings from earlier studies have suggested that GH action in the brain has an orexigenic effect [54]. Accordingly, transgenic mice overexpressing GH in the central nervous system develop hyperphagia-induced obesity [55]. GH-transgenic carps also exhibit increased food intake [56]. Further evidence of the orexigenic effect of GH came from studies that performed intracerebroventricular injections of GH in wild-type mice and observed higher food intake compared to vehicle-injected animals [17,55]. It makes sense from an evolutionary point of view to associate growth with increased hunger; therefore, the energy required for $\mathrm{GH}$-stimulated anabolic processes is guaranteed.

GH-induced increase in food intake seems to be mediated by ARH neurons that co-express NPY and agouti-related peptide (AgRP), which is a well-known neuronal population that stimulates feeding $[57,58]$. In accordance, GH overexpression in mice and fish induces upregulation of Agrp and/or Npy mRNA levels in the hypothalamus [55,56,59]. Furthermore, an acute GH injection increases Agrp and Npy mRNA levels in the hypothalamus of wild-type mice [17]. This is likely a direct effect of GH since approximately 95\% of ARH AgRP/NPY neurons express Ghr mRNA or GH-induced pSTAT5 $[17,34,35]$ (Figure 3A). Additionally, GH depolarizes the membrane potential of AgRP/NPY neurons, even in the presence of synaptic blockers [17]. In favor of the assumption that GH stimulates the activity of AgRP neurons in humans, circulating GH or IGF-1 levels exhibit a positive correlation with plasma AgRP levels in humans [60]. Moreover, plasma AgRP levels are high in patients with acromegaly, and pharmacological or surgical treatment reduces both GH secretion and plasma AgRP concentration [60].

Neurons that express proopiomelanocortin (POMC) in the ARH represent another key neuronal population involved in the regulation of feeding [61]. Approximately $60 \%$ of ARH POMC neurons exhibit pSTAT5 after an intracerebroventricular GH injection [62] (Figure 3A). Nevertheless, neither GH overexpression nor intracerebroventricular GH injection induce changes in hypothalamic Pomc expression $[17,55,56]$. Furthermore, GHR ablation in POMC-expressing cells does not elicit significant alterations in food intake in ad libitum fed mice nor after a period of food deprivation [62]. It is well documented that the injection of 2-deoxy-D-glucose (2DG) in rodents produces a glucoprivic condition which is followed by an acute increase in food intake [63-65]. Although 2DG injection increases the expression of Npy mRNA in the ARH, which could explain the 2DG-induced hyperphagia [65], another study suggested that NPY / AgRP neurons are not critical for the feeding responses to 2DG [64]. In this context, glucoprivic-induced hyperphagia was evaluated in knockout mice for GHR specifically in AgRP- or POMC-expressing cells. Notably, 2DG-induced hyperphagia is attenuated in mice lacking GHR either in AgRP neurons [17] or in POMC cells [62]. Thus, GH regulates glucoprivic-induced hyperphagia via these two major ARH neuronal populations. 


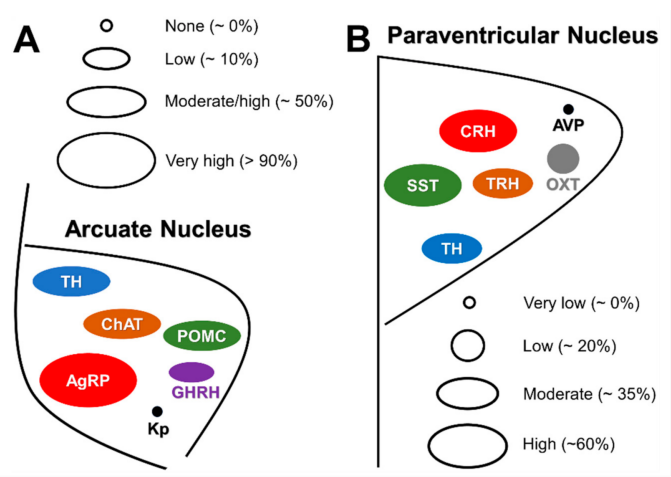

Figure 3. Neurochemical phenotype of GH-responsive neurons in the hypothalamic arcuate and paraventricular nuclei. (A) Scheme illustrating the approximate percentage of responsiveness to GH in arcuate nucleus neurons that express agouti-related peptide (AgRP), proopiomelanocortin (POMC), choline acetyltransferase (ChAT), tyrosine hydroxylase (TH), GH-releasing hormone (GHRH) and kisspeptins (Kp). (B) Scheme illustrating the approximate percentage of responsiveness to GH in hypothalamic paraventricular nucleus neurons that express somatostatin (SST), TH, corticotropinreleasing hormone $(\mathrm{CRH})$, thyrotropin-releasing hormone (TRH), oxytocin (OXT) and vasopressin $(\mathrm{AVP})$. The relative size of circles and ellipsoids indicates the approximate percentage of neurons in these nuclei which are responsive to GH.

Cholinergic neurons in the DMH and diagonal band of Broca (HBD) regulate food intake $[66,67]$. Choline acetyltransferase (ChAT) is a marker of cholinergic neurons and a population of ChAT-expressing neurons is also found in the ARH. ChAT neurons in the ARH co-express POMC and tyrosine hydroxylase (TH) [68,69]. Interestingly, 60\% and $84 \%$ ChAT neurons in the ARH and DMH, respectively, exhibit GH-induced pSTAT5 [70] (Figure $3 \mathrm{~A}$ ). To determine whether GH action on cholinergic cells regulates food intake and metabolism, a ChAT-specific GHR knockout mouse was generated. Although these mutants exhibited reduced hypothalamic Pomc mRNA expression when exposed to a high-fat diet, ablation of GHR in cholinergic cells caused no metabolic consequences [70]. Interestingly, HBD ChAT neurons in mice are not responsive to $\mathrm{GH}$, whereas $50 \%$ of cholinergic neurons in the rat HBD displayed GH-induced pSTAT5 [37]. Thus, it is possible that HBD ChAT-expressing neurons mediate the effects of GH on food intake in rats but not in mice.

Administration of the stomach-derived hormone ghrelin stimulates both GH secretion [4-7] and food intake [71]. However, the effects of ghrelin on food intake may be partially mediated by GH. Accordingly, GH action in the brain regulates the expression of GHS-R [72]. Noteworthily, GH-deficient or GHR-knockout mice manifest a blunted feeding response to ghrelin [71,73]. Pregnancy and lactation are physiological conditions that induce significant increases in food intake [74,75]. Remarkably, brain-specific GHR ablation decreases food intake and body adiposity during pregnancy, without affecting these parameters in non-pregnant or lactating mice [76]. Therefore, GH action in the brain regulates pregnancy-induced hyperphagia.

\subsection{GH Action in the Brain Modulates Insulin Sensitivity and Glucose Homeostasis}

Several hormones modulate whole-body glucose homeostasis through their action on the brain $[77,78]$. For example, leptin exerts its major effects on insulin sensitivity via the central nervous system [61]. Since GH also regulates insulin sensitivity, part of this effect may be mediated by the brain as well. Previous studies investigated the physiological role of GH signaling in leptin receptor (LepR)-expressing cells [79,80]. Notably, GHR ablation in LepR-expressing cells led to impaired hepatic insulin sensitivity $[79,80]$. In contrast, inactivation of GHR in specific populations of LepR-expressing neurons, including AgRP, POMC and steroidogenic factor 1 (SF1) cells, did not cause significant effects on glucose tolerance and insulin sensitivity $[17,62,76,80]$. Thus, a still-undisclosed population of LepR-expressing cells might mediate $\mathrm{GH}$ actions on insulin resistance. 
Approximately one third of the cholinergic pre-ganglionic parasympathetic neurons located in the dorsal motor nucleus of the vagus (DMX) express pSTAT5 after an acute GH injection [70]. DMX neurons are able to regulate pancreatic hormone secretion as well as hepatic glycogenolysis and glucose production. However, GHR ablation in cholinergic neurons does not produce alterations in glucose homeostasis in mice consuming normal chow or high-fat diets [70]. Thus, further studies are needed to determine the physiological role of GHR signaling in this population of DMX neurons.

Pregnant animals usually develop a transient insulin resistance which is compensated by increases in glucose-stimulated insulin secretion [81]. Hormones secreted during pregnancy such as prolactin and placental lactogens play a prominent role in gestational metabolic adaptions, especially inducing the expansion of pancreatic beta-cells $[82,83]$. Since GH secretion in humans and rodents augments during pregnancy [84], GH action in the brain may also modulate glucose homeostasis in this condition. Remarkably, systemic insulin sensitivity is greatly improved in pregnant mice lacking GHR in the brain or in LepR-expressing cells [76]. Thus, while prolactin secretion promotes beta-cell adaptations during pregnancy, central GH action is critical to induce the typical insulin resistance observed in pregnant mice.

Together with glucocorticoids, noradrenaline and glucagon, GH is considered a counter-regulatory hormone that is secreted during hypoglycemia $[77,85,86]$. Accordingly, defects in GH secretion favor spontaneous hypoglycemia and impair the counter-regulatory response (CRR) [87-89]. Neurons in the VMH are responsive to GH [36]. Additionally, VMH contains glucose-sensing neurons that represent a key relay station in the neural circuitry that produces the CRR $[77,78]$. Using SF1 expression to drive VMH-specific deletion of GHR in mice, reduced glycemia was observed in mutant mice treated with insulin compared to control animals, without affecting insulin sensitivity. In addition, the CRR induced by 2DG is significantly attenuated in mice carrying ablation of GHR in VMH cells [80]. Inactivation of GHR in LepR-expressing cells also impairs the CRR to hypoglycemia [80], which is in line with the high degree of co-localization between SF1 and LepR expression in the VMH [90]. Collectively, these findings indicate that central GH action in SF1/LepR-positive neurons is relevant for recovery from hypoglycemia.

\subsection{Central GH Action Regulates the Metabolic Responses to Calorie Restriction \\ 3.3.1. Central GHR Signaling Modulates Calorie Restriction-Induced Changes in Energy Expenditure}

GH secretion increases during prolonged food restriction or fasting [85,89]. However, the precise role of $\mathrm{GH}$ action during these situations has not been completely understood until recently. It is well known that AgRP/NPY neurons become activated during calorie restriction and these neurons play an important role in suppressing energy expenditure and inducing hunger $[57,58,91]$. Remarkably, AgRP-specific GHR ablation attenuates fasting-induced activation of ARH AgRP/NPY neurons [17]. Mice carrying genetic ablation of GHR in AgRP neurons are unable to develop important metabolic responses to calorie restriction. In this regard, while control animals present activation of the adrenal axis and suppression of thyroid function, reproduction and thermogenesis during food restriction, the absence of $\mathrm{GH}$ action on AgRP cells impairs these neuroendocrine adaptations [17]. Consequently, compared to control animals, the energy expenditure of mice carrying AgRP-specific GHR ablation is less suppressed by calorie restriction, resulting in higher weight loss [17]. Thus, GH action on AgRP neurons represents a starvation signal that triggers energy-saving neuroendocrine adaptations to conserve body energy stores. Notably, administration of the GHR antagonist pegvisomant in C57BL/ 6 mice was able to reproduce the phenotype of the animals with AgRP-specific GHR ablation since it partially prevented the progressive reduction in energy expenditure during food restriction [17]. Ablation of the Stat $5 a / b$ genes in AgRP neurons also partially prevents the neuroendocrine adaptations induced by calorie restriction, indicating STAT5 transcription factors as the major downstream signaling pathway recruited by GHR to induce these effects [92]. It is worth mentioning that ablation of GHR in POMC- or SF1-expressing cells does not produce 
significant effects in the metabolic responses to calorie restriction [62,80], whereas GHR deletion in the entire brain or restricted to LepR-expressing cells reproduces the phenotype exhibited by AgRP-specific knockout mice during calorie restriction [17]. Therefore, the central metabolic responses induced by GH during calorie restriction seem to be solely mediated by AgRP neurons and the ablation of GHR in additional neuronal populations causes no further effects.

\subsubsection{Central GH Action Is Necessary to Maintain Blood Glucose Levels During Food Restriction}

The maintenance of glycemia during prolonged food restriction requires numerous metabolic adaptations. The enzyme ghrelin O-acyltransferase (GOAT) is necessary for the generation of biologically active ghrelin. GOAT knockout mice present normal glycemia in ad libitum fed conditions, but after a few days of $60 \%$ calorie restriction, they exhibit hypoglycemia that can lead to death [89]. The lack of acyl-ghrelin (active form) in GOAT knockout mice prevents calorie-restriction-induced increases in plasma GH levels. Remarkably, GH replacement in GOAT knockout mice precludes the decrease in blood glucose levels during food restriction [89]. Other studies confirmed profound hypoglycemia in ghrelin-deficient mice during food restriction [93,94]. Thus, during prolonged food deprivation, ghrelin-induced GH secretion is necessary for the maintenance of glycemia and, consequently, to prevent death. Interestingly, blood glucose levels during $60 \%$ calorie restriction are not affected by GHR ablation in POMC or VMH neurons [62,80]. However, mice carrying inactivation of GHR in LepR- or AgRP-expressing neurons present a reduction in blood glucose levels during food restriction compared to control animals [17]. Therefore, GHR signaling in AgRP neurons that are also responsive to leptin is necessary for the maintenance of glycemia during prolonged food restriction.

\subsection{Adaptation Capacity to Aerobic Exercise Is Affected by Central GHR Signaling}

The hypothalamus not only regulates metabolism in basal conditions but also during exercise training. There is accumulating evidence indicating that $\mathrm{VMH}$ neurons are major regulators of metabolism during exercise. Hypothalamic ablation of SF1 prevents the beneficial metabolic effects of exercise [95]. Inactivation of Socs3 gene from SF1/VMH neurons also impairs exercise performance [96]. Of note, the suppressor of cytokine signaling 3 (SOCS3) is a major negative regulator of cytokine signaling [97,98]. Thus, SOCS3 ablation likely affects the responses to different hormones in the VMH, including leptin and GH. To investigate whether GH signaling in the hypothalamus or specifically in VMH neurons alters acute and chronic metabolic adaptations to exercise, mice carrying ablation of GHR in LepR or SF1 cells were subjected to 8 weeks of treadmill running training [99]. Remarkably, while GHR deletion in LepR-expressing cells led to improved aerobic performance, GHR ablation in SF1 cells prevented improvements in running capacity [99]. These effects are possibly associated with modified glycemic responses to exercise, since SF1 GHR and LepR GHR knockout mice exhibited distinct changes in blood glucose levels in response to acute exercise [99].

\section{Neurotropic Effects of GH on ARH Neurons}

$\mathrm{GH}$ is an important growth factor in several peripheral tissues and also in the brain. As previously mentioned, GH not only modulates synaptic plasticity in the hippocampus [43-45] and amygdala [39], but this hormone also has important neurotropic effects on the development of ARH neurons that regulate metabolism [100,101]. It is well documented that leptin is required for the development of axonal projections of ARH neurons to post-synaptic targets such as the PVH [102,103]. Interestingly, GH- or GHR-deficient mice exhibit reduced axonal projections from ARH AgRP and POMC neurons to the PVH, similarly to that observed in leptin- or LepR-deficient mice [100,101]. However, GH or GHR deficiency leads to severe growth deficits as well as numerous metabolic and endocrine alterations. Thus, the study of mice carrying ablation of GHR specifically in LepR, AgRP or POMC neurons is an interesting approach to clarify whether GHR signaling, without 
those confounding factors, is required for the development of AgRP and POMC axonal projections [62,100]. Confirming a direct neurotropic effect of GH in ARH neurons, GHR ablation in LepR-expressing cells decreased the density of both AgRP and POMC axonal projections to hypothalamic post-synaptic targets. When GHR deletion was restricted to AgRP neurons, only AgRP axonal projections were reduced, whereas a normal POMC innervation was observed [100]. Of note, mice carrying ablation of Stat5a/Stat5b genes in AgRP neurons show normal AgRP axonal projections, suggesting that STAT5-independent signaling pathways are involved in the neurotropic effects of GH [92]. Furthermore, GHR ablation specifically in POMC neurons did not affect POMC axonal projections [62]. The percentage of ARH AgRP neurons that are responsive to $\mathrm{GH}$ is much higher than that of POMC neurons $[17,62]$, which could explain the minor neurotropic effects of GH when the entire population of POMC neurons is analyzed. Therefore, the central regulation of metabolism by GH may involve the neurotropic effects of GH in hypothalamic neurons that control energy and glucose homeostasis. Whether these neurotropic effects are ubiquitously observed in other neuronal populations responsive to GH is still unknown.

\section{Future Perspectives}

Table 1 summarizes the published articles so far that used mouse models with ablation of GHR in specific neuronal populations to investigate the physiological role of central $\mathrm{GH}$ action. The importance of GHR signaling in several newly described populations of GH-responsive neurons remains undetermined [36,37]. Recently, our research group identified the neurochemical phenotype of GH-responsive cells in mouse PVH [104]. The PVH contains several neurochemically defined neuronal populations [105], so the identification of those that are responsive to $\mathrm{GH}$ allows understanding the possible physiological importance of GHR signaling in this hypothalamic nucleus. We found that $38 \%, 55 \%, 35 \%$ and $63 \%$ of TH, SST, thyrotropin-releasing hormone (TRH) and corticotropin-releasing hormone (CRH) neurons exhibited GH-induced pSTAT5, respectively [104] (Figure 3B). The majority of neuroendocrine SST, TRH and CRH neurons were responsive to GH, indicating that central GH signaling probably regulates somatotropic, thyroid and adrenal endocrine axes (Figure 2). However, non-neuroendocrine neurons were also responsive to $\mathrm{GH}$ in the $\mathrm{PVH}$, including $67 \%, 32 \%$ and $74 \%$ of non-neuroendocrine $\mathrm{TH}, \mathrm{TRH}$ and CRH PVH neurons, respectively [104]. This study gives an idea about the diversity of functions that central GHR signaling may regulate in one specific hypothalamic nucleus. However, follow-up physiological studies investigating the role of GHR signaling in each PVH neuronal population are warranted.

Table 1. Summary of the published articles that used mouse models with ablation of GH receptor in specific neuronal populations to investigate the physiological role of central GH action.

\begin{tabular}{|c|c|c|}
\hline Neuronal Population & Physiological Aspects Regulated by Central GH Receptor Signaling & Reference \\
\hline \multirow{3}{*}{ Nestin-derived cells (entire brain) } & $\begin{array}{l}\text { Neuroendocrine adaptations that affect energy expenditure during } \\
\text { food restriction }\end{array}$ & [17] \\
\hline & Regulation of GH secretion via a negative feedback loop & [33] \\
\hline & $\begin{array}{c}\text { Food intake, fat retention, as well as insulin and leptin sensitivity } \\
\text { during pregnancy }\end{array}$ & [76] \\
\hline
\end{tabular}


Table 1. Cont.

\begin{tabular}{|c|c|c|}
\hline Neuronal Population & Physiological Aspects Regulated by Central GH Receptor Signaling & Reference \\
\hline \multirow{8}{*}{ LepR-expressing cells } & Hepatic glucose production and insulin sensitivity & [79] \\
\hline & $\begin{array}{l}\text { Neuroendocrine adaptations that affect energy expenditure during } \\
\text { food restriction }\end{array}$ & [17] \\
\hline & Maintenance of glycemia during prolonged food restriction & [17] \\
\hline & Glucoprivic hyperphagia & [17] \\
\hline & $\begin{array}{l}\text { Food intake, fat retention, as well as insulin and leptin sensitivity } \\
\text { during pregnancy }\end{array}$ & {$[76]$} \\
\hline & Aerobic performance and metabolic adaptations to chronic exercise & [99] \\
\hline & Recovery from hypoglycemia and counter-regulatory response & [80] \\
\hline & Trophic effects on the formation of POMC and AgRP axonal projections & [100] \\
\hline TH-expressing cells & Regulation of GH secretion via a negative feedback loop & [33] \\
\hline Dopamine transporter-expressing cells & No function identified yet & [33] \\
\hline $\begin{array}{c}\text { Dopamine } \\
\beta \text {-hydroxylase-expressing cells }\end{array}$ & No function identified yet & [33] \\
\hline \multirow{4}{*}{ AgRP-expressing neurons } & $\begin{array}{l}\text { Neuroendocrine adaptations that affect energy expenditure during } \\
\text { food restriction }\end{array}$ & [17] \\
\hline & Maintenance of glycemia during prolonged food restriction & [17] \\
\hline & Glucoprivic hyperphagia & [17] \\
\hline & Trophic effects on the formation of AgRP axonal projections & [100] \\
\hline Cholinergic cells & No function identified yet & [70] \\
\hline Kisspeptin-expressing neurons & $\begin{array}{c}\text { Regulation of the hypothalamic expression of transcripts that modulate } \\
\text { the hypothalamic-pituitary-gonadal axis }\end{array}$ & [106] \\
\hline POMC-expressing neurons & Glucoprivic hyperphagia & [62] \\
\hline \multirow{2}{*}{ SF1-expressing cells (VMH neurons) } & Recovery from hypoglycemia and counter-regulatory response & [80] \\
\hline & Aerobic performance and metabolic adaptations to exercise & [99] \\
\hline
\end{tabular}

In another study, our research group disclosed that several neuronal populations that express TH are responsive to GH, including neurons in the ARH, PVH (Figure 3), PV and locus coeruleus (LC) [33]. Of note, LC is the major source of noradrenergic projections to the forebrain [107], which are vital for the control of physiological responses to stress. Importantly, GH-responsive neurons are also enriched in several other brain structures involved in stress responses, including BNST, the central nucleus of the amygdala and $\mathrm{CRH}$-expressing cells in the PVH (Figure 3B). Thus, central GHR signaling likely plays a significant role in modulating the central responses to stress, including situations such as glucoprivation, food restriction and physical exercise. Therefore, based on the aforementioned neuroanatomical evidence, it is imperative that future studies investigate how central GH actions can influence the neurocircuits that trigger stress responses, assessing possible consequences on metabolism and behavioral regulation.

\section{Conclusions}

This review article presents an overview of recent research data indicating that central GHR signaling regulates metabolism, particularly in situations of metabolic stress. The high responsiveness to $\mathrm{GH}$ in hypothalamic and extra-hypothalamic neuronal populations that control metabolism, especially the $\mathrm{ARH}, \mathrm{VMH}$, and $\mathrm{PVH}$, suggests that circulating $\mathrm{GH}$ levels may represent a cue that conveys homeostatic information to the brain to produce metabolic adjustments in order to promote energy homeostasis. Accordingly, GH secretion is elevated in numerous situations of metabolic stress, including hypoglycemia [85], prolonged calorie restriction [89], and exercise [108]. Elevated GH secretion is also observed in physiological situations characterized by additional metabolic exigencies such as puberty $[106,109]$ and pregnancy [84]. Thus, in addition to its well-known effects of stimulating protein synthesis, tissue growth, and cell proliferation, GH should be considered 
a metabolic hormone which, besides acting in peripheral tissues, also fulfills important functions in the central nervous system. Finally, the recognition of the central effects of GH regulating metabolism can provide significant new contributions to the understanding of metabolic changes that occur in different physiological or pathological conditions.

Funding: We thank Fundacao de Amparo a Pesquisa do Estado de Sao Paulo (FAPESP/Brazil) for the financial support (grants number: 2016/20897-3 to F.W., 2016/09679-4 to I.C.F., 2017/16473-6 to M.M., 2019/21707-1 to R.F., and 2020/01318-8 to J.D.J.). J.D.J. is the investigator of the Conselho Nacional de Desenvolvimento Cientifico e Tecnologico (CNPq/Brazil).

Institutional Review Board Statement: Not applicable.

Informed Consent Statement: Not applicable.

Data Availability Statement: No new data were created or analyzed in this study. Data sharing is not applicable to this article.

Conflicts of Interest: The authors declare no conflict of interest.

\section{References}

1. Steyn, F.J.; Tolle, V.; Chen, C.; Epelbaum, J. Neuroendocrine regulation of growth hormone secretion. Compr. Physiol. 2016, 6, 687-735. [PubMed]

2. Murray, P.G.; Higham, C.E.; Clayton, P.E. 60 years of neuroendocrinology: The hypothalamo-GH axis: The past 60 years. J. Endocrinol. 2015, 226, T123-T140. [CrossRef] [PubMed]

3. Donahue, L.R.; Beamer, W.G. Growth hormone deficiency in 'little' mice results in aberrant body composition, reduced insulin-like growth factor-I and insulin-like growth factor-binding protein-3 (IGFBP-3), but does not affect IGFBP-2, -1 or -4. J. Endocrinol. 1993, 136, 91-104. [CrossRef] [PubMed]

4. Kojima, M.; Hosoda, H.; Date, Y.; Nakazato, M.; Matsuo, H.; Kangawa, K. Ghrelin is a growth-hormone-releasing acylated peptide from stomach. Nature 1999, 402, 656-660. [CrossRef]

5. Peino, R.; Baldelli, R.; Rodriguez-Garcia, J.; Rodriguez-Segade, S.; Kojima, M.; Kangawa, K.; Arvat, E.; Ghigo, E.; Dieguez, C.; Casanueva, F.F. Ghrelin-induced growth hormone secretion in humans. Eur. J. Endocrinol. 2000, 143, R11-R14. [CrossRef]

6. Wren, A.M.; Small, C.J.; Ward, H.L.; Murphy, K.G.; Dakin, C.L.; Taheri, S.; Kennedy, A.R.; Roberts, G.H.; Morgan, D.G.; Ghatei, M.A.; et al. The novel hypothalamic peptide ghrelin stimulates food intake and growth hormone secretion. Endocrinology 2000, 141, 4325-4328. [CrossRef]

7. Seoane, L.M.; Tovar, S.; Baldelli, R.; Arvat, E.; Ghigo, E.; Casanueva, F.F.; Dieguez, C. Ghrelin elicits a marked stimulatory effect on GH secretion in freely-moving rats. Eur. J. Endocrinol. 2000, 143, R7-R9. [CrossRef]

8. Reichenbach, A.; Steyn, F.J.; Sleeman, M.W.; Andrews, Z.B. Ghrelin receptor expression and colocalization with anterior pituitary hormones using a GHSR-GFP mouse line. Endocrinology 2012, 153, 5452-5466. [CrossRef]

9. Mano-Otagiri, A.; Nemoto, T.; Sekino, A.; Yamauchi, N.; Shuto, Y.; Sugihara, H.; Oikawa, S.; Shibasaki, T. Growth hormonereleasing hormone (GHRH) neurons in the arcuate nucleus (Arc) of the hypothalamus are decreased in transgenic rats whose expression of ghrelin receptor is attenuated: Evidence that ghrelin receptor is involved in the up-regulation of GHRH expression in the arc. Endocrinology 2006, 147, 4093-4103.

10. Rabkin, R.; Fervenza, F.C.; Maidment, H.; Ike, J.; Hintz, R.; Liu, F.; Bloedow, D.C.; Hoffman, A.R.; Gesundheit, N. Pharmacokinetics of insulin-like growth factor-1 in advanced chronic renal failure. Kidney Int. 1996, 49, 1134-1140. [CrossRef]

11. List, E.O.; Berryman, D.E.; Funk, K.; Jara, A.; Kelder, B.; Wang, F.; Stout, M.B.; Zhi, X.; Sun, L.; White, T.A.; et al. Liver-specific GH receptor gene-disrupted (LiGHRKO) mice have decreased endocrine IGH-I, increased local IGH-I, and altered body size, body composition, and adipokine profiles. Endocrinology 2014, 155, 1793-1805. [CrossRef] [PubMed]

12. Fan, Y.; Menon, R.K.; Cohen, P.; Hwang, D.; Clemens, T.; DiGirolamo, D.J.; Kopchick, J.J.; Le Roith, D.; Trucco, M.; Sperling, M.A. Liver-specific deletion of the growth hormone receptor reveals essential role of growth hormone signaling in hepatic lipid metabolism. J. Biol. Chem. 2009, 284, 19937-19944. [CrossRef] [PubMed]

13. Kopchick, J.J. Lessons learned from studies with the growth hormone receptor. Growth Horm. IGF Res. 2016, 28, 21-25. [CrossRef] [PubMed]

14. Kineman, R.D.; Del Rio-Moreno, M.; Sarmento-Cabral, A. 40 years of IGF1: Understanding the tissue-specific roles of IGF1/IGF1R in regulating metabolism using the Cre/loxP system. J. Mol. Endocrinol. 2018, 61, T187-T198. [CrossRef] [PubMed]

15. List, E.O.; Berryman, D.E.; Jensen, E.A.; Kulkarni, P.; McKenna, S.; Kopchick, J.J. New insights of growth hormone (GH) actions from tissue-specific GH receptor knockouts in mice. Arch. Endocrinol. Metab. 2019, 63, 557-567. [CrossRef] [PubMed]

16. List, E.O.; Duran-Ortiz, S.; Kopchick, J.J. Effects of tissue-specific GH receptor knockouts in mice. Mol. Cell. Endocrinol. 2020, 515, 110919. [CrossRef]

17. Furigo, I.C.; Teixeira, P.D.S.; de Souza, G.O.; Couto, G.C.L.; Romero, G.G.; Perello, M.; Frazao, R.; Elias, L.L.; Metzger, M.; List, E.O.; et al. Growth hormone regulates neuroendocrine responses to weight loss via AgRP neurons. Nat. Commun. 2019, 10, 662. [CrossRef] 
18. Hussain, M.A.; Schmitz, O.; Mengel, A.; Glatz, Y.; Christiansen, J.S.; Zapf, J.; Froesch, E.R. Comparison of the effects of growth hormone and insulin-like growth factor I on substrate oxidation and on insulin sensitivity in growth hormone-deficient humans. J. Clin. Invest. 1994, 94, 1126-1133. [CrossRef]

19. Nielsen, S.; Moller, N.; Christiansen, J.S.; Jorgensen, J.O. Pharmacological antilipolysis restores insulin sensitivity during growth hormone exposure. Diabetes 2001, 50, 2301-2308. [CrossRef]

20. Sakharova, A.A.; Horowitz, J.F.; Surya, S.; Goldenberg, N.; Harber, M.P.; Symons, K.; Barkan, A. Role of growth hormone in regulating lipolysis, proteolysis, and hepatic glucose production during fasting. J. Clin. Endocrinol. Metab. 2008, 93, 2755-2759. [CrossRef]

21. Sharma, R.; Kopchick, J.J.; Puri, V.; Sharma, V.M. Effect of growth hormone on insulin signaling. Mol. Cell. Endocrinol. 2020, 518, 111038. [CrossRef]

22. Donato, J., Jr. The central nervous system as a promising target to treat diabetes mellitus. Curr. Top. Med. Chem. 2012, 12, 2070-2081. [CrossRef] [PubMed]

23. Brüning, J.C.; Gautam, D.; Burks, D.J.; Gillette, J.; Schubert, M.; Orban, P.C.; Klein, R.; Krone, W.; Müller-Wieland, D.; Kahn, C.R. Role of brain insulin receptor in control of body weight and reproduction. Science 2000, 289, 2122-2125. [CrossRef] [PubMed]

24. Berglund, E.D.; Vianna, C.R.; Donato, J., Jr.; Kim, M.H.; Chuang, J.C.; Lee, C.E.; Lauzon, D.A.; Lin, P.; Brule, L.J.; Scott, M.M.; et al. Direct leptin action on pomc neurons regulates glucose homeostasis and hepatic insulin sensitivity in mice. J. Clin. Investig. 2012, 122, 1000-1009. [CrossRef] [PubMed]

25. Cohen, P.; Zhao, C.; Cai, X.; Montez, J.M.; Rohani, S.C.; Feinstein, P.; Mombaerts, P.; Friedman, J.M. Selective deletion of leptin receptor in neurons leads to obesity. J. Clin. Invest. 2001, 108, 1113-1121. [CrossRef] [PubMed]

26. Ulrich-Lai, Y.M.; Herman, J.P. Neural regulation of endocrine and autonomic stress responses. Nat. Rev. Neurosci. 2009, 10, 397-409. [CrossRef]

27. Seoane-Collazo, P.; Ferno, J.; Gonzalez, F.; Dieguez, C.; Leis, R.; Nogueiras, R.; Lopez, M. Hypothalamic-autonomic control of energy homeostasis. Endocrine 2015, 50, 276-291. [CrossRef] [PubMed]

28. Burton, K.A.; Kabigting, E.B.; Clifton, D.K.; Steiner, R.A. Growth hormone receptor messenger ribonucleic acid distribution in the adult male rat brain and its colocalization in hypothalamic somatostatin neurons. Endocrinology 1992, 131, 958-963.

29. Walsh, R.J.; Mangurian, L.P.; Posner, B.I. The distribution of lactogen receptors in the mammalian hypothalamus: An in vitro autoradiographic analysis of the rabbit and rat. Brain Res. 1990, 530, 1-11. [CrossRef]

30. Pellegrini, E.; Bluet-Pajot, M.T.; Mounier, F.; Bennett, P.; Kordon, C.; Epelbaum, J. Central administration of a growth hormone $(\mathrm{GH})$ receptor mRNA antisense increases GH pulsatility and decreases hypothalamic somatostatin expression in rats. J. Neurosci. 1996, 16, 8140-8148. [CrossRef]

31. Kastrup, Y.; Le Greves, M.; Nyberg, F.; Blomqvist, A. Distribution of growth hormone receptor mRNA in the brain stem and spinal cord of the rat. Neuroscience 2005, 130, 419-425. [CrossRef] [PubMed]

32. Burton, K.A.; Kabigting, E.B.; Steiner, R.A.; Clifton, D.K. Identification of target cells for growth hormone's action in the arcuate nucleus. Am. J. Physiol. 1995, 269, E716-E722. [CrossRef] [PubMed]

33. Wasinski, F.; Pedroso, J.A.B.; Dos Santos, W.O.; Furigo, I.C.; Garcia-Galiano, D.; Elias, C.F.; List, E.O.; Kopchick, J.J.; Szawka, R.E.; Donato, J., Jr. Tyrosine hydroxylase neurons regulate growth hormone secretion via short-loop negative feedback. J. Neurosci. 2020, 40, 4309-4322. [CrossRef] [PubMed]

34. Chan, Y.; Steiner, R.; Clifton, D. Regulation of hypothalamic neuropeptide-Y neurons by growth hormone in the rat. Endocrinology 1996, 137, 1319-1325. [CrossRef] [PubMed]

35. Kamegai, J.; Minami, S.; Sugihara, H.; Hasegawa, O.; Higuchi, H.; Wakabayashi, I. Growth hormone receptor gene is expressed in neuropeptide $Y$ neurons in hypothalamic arcuate nucleus of rats. Endocrinology 1996, 137, 2109-2112. [CrossRef]

36. Furigo, I.C.; Metzger, M.; Teixeira, P.D.; Soares, C.R.; Donato, J., Jr. Distribution of growth hormone-responsive cells in the mouse brain. Brain Struct. Funct. 2017, 222, 341-363. [CrossRef]

37. Wasinski, F.; Klein, M.O.; Bittencourt, J.C.; Metzger, M.; Donato, J., Jr. Distribution of growth hormone-responsive cells in the brain of rats and mice. Brain Res. 2021, 1751, 147189. [CrossRef]

38. Wasinski, F.; Frazão, R.; Donato, J.J. Effects of growth hormone in the central nervous system. Arch. Endocrinol. Metab. 2019, 63, 549-556. [CrossRef]

39. Gisabella, B.; Farah, S.; Peng, X.; Burgos-Robles, A.; Lim, S.H.; Goosens, K.A. Growth hormone biases amygdala network activation after fear learning. Transl. Psychiatry 2016, 6, e960. [CrossRef]

40. Meyer, R.M.; Burgos-Robles, A.; Liu, E.; Correia, S.S.; Goosens, K.A. A ghrelin-growth hormone axis drives stress-induced vulnerability to enhanced fear. Mol. Psychiatry 2014, 19, 1284-1294. [CrossRef]

41. Deijen, J.B.; de Boer, H.; van der Veen, E.A. Cognitive changes during growth hormone replacement in adult men. Psychoneuroendocrinology 1998, 23, 45-55. [CrossRef]

42. Maruff, P.; Falleti, M. Cognitive function in growth hormone deficiency and growth hormone replacement. Horm. Res. 2005, 64 (Suppl. 3), 100-108. [CrossRef] [PubMed]

43. Mahmoud, G.S.; Grover, L.M. Growth hormone enhances excitatory synaptic transmission in area CA1 of rat hippocampus. J. Neurophysiol. 2006, 95, 2962-2974. [CrossRef] [PubMed] 
44. Molina, D.P.; Ariwodola, O.J.; Linville, C.; Sonntag, W.E.; Weiner, J.L.; Brunso-Bechtold, J.K.; Adams, M.M. Growth hormone modulates hippocampal excitatory synaptic transmission and plasticity in old rats. Neurobiol. Aging 2012, 33, 1938-1949. [CrossRef]

45. Ramis, M.; Sarubbo, F.; Sola, J.; Aparicio, S.; Garau, C.; Miralles, A.; Esteban, S. Cognitive improvement by acute growth hormone is mediated by NMDA and AMPA receptors and MEK pathway. Prog. Neuropsychopharmacol. Biol. Psychiatry 2013, 45, 11-20. [CrossRef]

46. Furigo, I.C.; Melo, H.M.; Lyra, E.S.N.M.; Ramos-Lobo, A.M.; Teixeira, P.D.S.; Buonfiglio, D.C.; Wasinski, F.; Lima, E.R.; Higuti, E.; Peroni, C.N.; et al. Brain STAT5 signaling modulates learning and memory formation. Brain Struct. Funct. 2018, 223, $2229-2241$. [CrossRef]

47. Kinney, B.A.; Coschigano, K.T.; Kopchick, J.J.; Steger, R.W.; Bartke, A. Evidence that age-induced decline in memory retention is delayed in growth hormone resistant GH-R-KO (Laron) mice. Physiol. Behav. 2001, 72, 653-660. [CrossRef]

48. Kinney-Forshee, B.A.; Kinney, N.E.; Steger, R.W.; Bartke, A. Could a deficiency in growth hormone signaling be beneficial to the aging brain? Physiol. Behav. 2004, 80, 589-594. [CrossRef]

49. Basu, A.; McFarlane, H.G.; Kopchick, J.J. Spatial learning and memory in male mice with altered growth hormone action. Horm. Behav. 2017, 93, 18-30. [CrossRef]

50. Bomfim, T.R.; Forny-Germano, L.; Sathler, L.B.; Brito-Moreira, J.; Houzel, J.C.; Decker, H.; Silverman, M.A.; Kazi, H.; Melo, H.M.; McClean, P.L.; et al. An anti-diabetes agent protects the mouse brain from defective insulin signaling caused by Alzheimer's disease- associated A $\beta$ oligomers. J. Clin. Investig. 2012, 122, 1339-1353. [CrossRef]

51. Schioth, H.B.; Frey, W.H.; Brooks, S.J.; Benedict, C. Insulin to treat Alzheimer's disease: Just follow your nose? Expert Rev. Clin. Pharmacol. 2012, 5, 17-20. [CrossRef] [PubMed]

52. Talbot, K.; Wang, H.Y.; Kazi, H.; Han, L.Y.; Bakshi, K.P.; Stucky, A.; Fuino, R.L.; Kawaguchi, K.R.; Samoyedny, A.J.; Wilson, R.S.; et al Demonstrated brain insulin resistance in Alzheimer's disease patients is associated with IGF-1 resistance, IRS-1 dysregulation, and cognitive decline. J. Clin. Investig. 2012, 122, 1316-1338. [CrossRef] [PubMed]

53. Duran-Ortiz, S.; Noboa, V.; Kopchick, J.J. Disruption of the GH receptor gene in adult mice and in insulin sensitive tissues. Growth Horm. IGF Res. 2018, 38, 3-7. [CrossRef] [PubMed]

54. Nyberg, F. Growth hormone in the brain: Characteristics of specific brain targets for the hormone and their functional significance. Front. Neuroendocrinol. 2000, 21, 330-348. [CrossRef] [PubMed]

55. Bohlooly, Y.M.; Olsson, B.; Bruder, C.E.; Linden, D.; Sjogren, K.; Bjursell, M.; Egecioglu, E.; Svensson, L.; Brodin, P.; Waterton, J.C.; et al. Growth hormone overexpression in the central nervous system results in hyperphagia-induced obesity associated with insulin resistance and dyslipidemia. Diabetes 2005, 54, 51-62. [CrossRef] [PubMed]

56. Zhong, C.; Song, Y.; Wang, Y.; Zhang, T.; Duan, M.; Li, Y.; Liao, L.; Zhu, Z.; Hu, W. Increased food intake in growth hormone-transgenic common carp (Cyprinus carpio L.) may be mediated by upregulating agouti-related protein (AgRP). Gen. Comp. Endocrinol. 2013, 192, 81-88. [CrossRef]

57. Aponte, Y.; Atasoy, D.; Sternson, S.M. AgRP neurons are sufficient to orchestrate feeding behavior rapidly and without training. Nat. Neurosci. 2011, 14, 351-355. [CrossRef]

58. Krashes, M.J.; Koda, S.; Ye, C.; Rogan, S.C.; Adams, A.C.; Cusher, D.S.; Maratos-Flier, E.; Roth, B.L.; Lowell, B.B. Rapid, reversible activation of AgRP neurons drives feeding behavior in mice. J. Clin. Investig. 2011, 121, 1424-1428. [CrossRef]

59. Kim, J.H.; Leggatt, R.A.; Chan, M.; Volkoff, H.; Devlin, R.H. Effects of chronic growth hormone overexpression on appetiteregulating brain gene expression in coho salmon. Mol. Cell. Endocrinol. 2015, 413, 178-188. [CrossRef]

60. Freda, P.U.; Reyes-Vidal, C.; Jin, Z.; Pugh, M.; Panigrahi, S.K.; Bruce, J.N.; Wardlaw, S.L. Plasma agouti-related protein levels in acromegaly and effects of surgical or pegvisomant therapy. J. Clin. Endocrinol. Metab. 2019, 104, 5453-5461. [CrossRef]

61. Ramos-Lobo, A.M.; Donato, J., Jr. The role of leptin in health and disease. Temperature 2017, 4, 258-291. [CrossRef] [PubMed]

62. Quaresma, P.G.F.; Teixeira, P.D.S.; Furigo, I.C.; Wasinski, F.; Couto, G.C.; Frazao, R.; List, E.O.; Kopchick, J.J.; Donato, J., Jr. Growth hormone/STAT5 signaling in proopiomelanocortin neurons regulates glucoprivic hyperphagia. Mol. Cell. Endocrinol. 2019, 498, 110574. [CrossRef] [PubMed]

63. Thompson, C.I.; Zagon, I.S.; McLaughlin, P.J. Hypophagia follows the initial hyperphagia produced by 2-deoxy-D-glucose in rats. Physiol. Behav. 1979, 23, 187-190. [CrossRef]

64. Luquet, S.; Phillips, C.T.; Palmiter, R.D. NPY/AgRP neurons are not essential for feeding responses to glucoprivation. Peptides 2007, 28, 214-225. [CrossRef]

65. Ozawa, Y.; Arima, H.; Watanabe, M.; Shimizu, H.; Ito, Y.; Banno, R.; Sugimura, Y.; Ozaki, N.; Nagasaki, H.; Oiso, Y. Repeated glucoprivation delayed hyperphagic responses while activating neuropeptide Y neurons in rats. Peptides 2011, 32, 763-769. [CrossRef]

66. Jeong, J.H.; Lee, D.K.; Jo, Y.H. Cholinergic neurons in the dorsomedial hypothalamus regulate food intake. Mol. Metab. 2017, 6, 306-312. [CrossRef]

67. Herman, A.M.; Ortiz-Guzman, J.; Kochukov, M.; Herman, I.; Quast, K.B.; Patel, J.M.; Tepe, B.; Carlson, J.C.; Ung, K.; Selever, J.; et al. A cholinergic basal forebrain feeding circuit modulates appetite suppression. Nature 2016, 538, 253-256. [CrossRef]

68. Meister, B.; Gomuc, B.; Suarez, E.; Ishii, Y.; Durr, K.; Gillberg, L. Hypothalamic proopiomelanocortin (POMC) neurons have a cholinergic phenotype. Eur. J. Neurosci. 2006, 24, 2731-2740. [CrossRef] 
69. Jeong, J.H.; Woo, Y.J.; Chua, S., Jr.; Jo, Y.H. Single-cell gene expression analysis of cholinergic neurons in the arcuate nucleus of the hypothalamus. PLoS ONE 2016, 11, e0162839. [CrossRef]

70. Quaresma, P.G.F.; Teixeira, P.D.S.; Wasinski, F.; Campos, A.M.P.; List, E.O.; Kopchick, J.J.; Donato, J., Jr. Cholinergic neurons in the hypothalamus and dorsal motor nucleus of the vagus are directly responsive to growth hormone. Life Sci. 2020, $259,118229$. [CrossRef]

71. Tschop, M.; Smiley, D.L.; Heiman, M.L. Ghrelin induces adiposity in rodents. Nature 2000, 407, 908-913. [CrossRef] [PubMed]

72. Nogueiras, R.; Tovar, S.; Mitchell, S.E.; Rayner, D.V.; Archer, Z.A.; Dieguez, C.; Williams, L.M. Regulation of growth hormone secretagogue receptor gene expression in the arcuate nuclei of the rat by leptin and ghrelin. Diabetes 2004, 53, 2552-2558. [CrossRef] [PubMed]

73. Egecioglu, E.; Bjursell, M.; Ljungberg, A.; Dickson, S.L.; Kopchick, J.J.; Bergstrom, G.; Svensson, L.; Oscarsson, J.; Tornell, J.; Bohlooly, Y.M. Growth hormone receptor deficiency results in blunted ghrelin feeding response, obesity, and hypolipidemia in mice. Am. J. Physiol. Endocrinol. Metab. 2006, 290, E317-E325. [CrossRef] [PubMed]

74. Ladyman, S.R.; Augustine, R.A.; Grattan, D.R. Hormone interactions regulating energy balance during pregnancy. J. Neuroendocrinol. 2010, 22, 805-817. [CrossRef] [PubMed]

75. Zampieri, T.T.; Ramos-Lobo, A.M.; Furigo, I.C.; Pedroso, J.A.; Buonfiglio, D.C.; Donato, J., Jr. Socs3 deficiency in leptin receptorexpressing cells mitigates the development of pregnancy-induced metabolic changes. Mol. Metab 2015, 4, 237-245. [CrossRef] [PubMed]

76. Teixeira, P.D.S.; Couto, G.C.; Furigo, I.C.; List, E.O.; Kopchick, J.J.; Donato, J., Jr. Central growth hormone action regulates metabolism during pregnancy. Am. J. Physiol. Endocrinol. Metab. 2019, 317, E925-E940. [CrossRef]

77. Verberne, A.J.; Sabetghadam, A.; Korim, W.S. Neural pathways that control the glucose counterregulatory response. Front. Neurosci. 2014, 8, 38. [CrossRef]

78. Meek, T.H.; Nelson, J.T.; Matsen, M.E.; Dorfman, M.D.; Guyenet, S.J.; Damian, V.; Allison, M.B.; Scarlett, J.M.; Nguyen, H.T.; Thaler, J.P.; et al. Functional identification of a neurocircuit regulating blood glucose. Proc. Natl. Acad. Sci. USA 2016, 113, E2073-E2082. [CrossRef]

79. Cady, G.; Landeryou, T.; Garratt, M.; Kopchick, J.J.; Qi, N.; Garcia-Galiano, D.; Elias, C.F.; Myers, M.G., Jr.; Miller, R.A.; Sandoval, D.A.; et al. Hypothalamic growth hormone receptor (GHR) controls hepatic glucose production in nutrient-sensing leptin receptor (LepRB) expressing neurons. Mol. Metab. 2017, 6, 393-405. [CrossRef]

80. Furigo, I.C.; de Souza, G.O.; Teixeira, P.D.S.; Guadagnini, D.; Frazao, R.; List, E.O.; Kopchick, J.J.; Prada, P.O.; Donato, J., Jr. Growth hormone enhances the recovery of hypoglycemia via ventromedial hypothalamic neurons. FASEB J. 2019, 33, 11909-11924. [CrossRef]

81. Sorenson, R.L.; Brelje, T.C. Adaptation of islets of langerhans to pregnancy: Beta-cell growth, enhanced insulin secretion and the role of lactogenic hormones. Horm. Metab. Res. 1997, 29, 301-307. [CrossRef] [PubMed]

82. Banerjee, R.R.; Cyphert, H.A.; Walker, E.M.; Chakravarthy, H.; Peiris, H.; Gu, X.; Liu, Y.; Conrad, E.; Goodrich, L.; Stein, R.W.; et al. Gestational diabetes mellitus from inactivation of prolactin receptor and MafB in islet $\beta$-cells. Diabetes 2016, 65, 2331-2341. [CrossRef] [PubMed]

83. Huang, C.; Snider, F.; Cross, J.C. Prolactin receptor is required for normal glucose homeostasis and modulation of $\beta$-cell mass during pregnancy. Endocrinology 2009, 150, 1618-1626. [CrossRef] [PubMed]

84. Gatford, K.L.; Muhlhausler, B.S.; Huang, L.; Sim, P.S.; Roberts, C.T.; Velhuis, J.D.; Chen, C. Rising maternal circulating GH during murine pregnancy suggests placental regulation. Endocr. Connect. 2017, 6, 260-266. [CrossRef] [PubMed]

85. Roth, J.; Glick, S.M.; Yalow, R.S.; Berson, S.A. Hypoglycemia: A potent stimulus to secretion of growth hormone. Science 1963, 140, 987-988. [CrossRef]

86. Lee, J.; Kim, K.; Cho, J.H.; Bae, J.Y.; O'Leary, T.P.; Johnson, J.D.; Bae, Y.C.; Kim, E.K. Insulin synthesized in the paraventricular nucleus of the hypothalamus regulates pituitary growth hormone production. JCI Insight 2020, 5, e135412. [CrossRef]

87. Hussain, K.; Hindmarsh, P.; Aynsley-Green, A. Spontaneous hypoglycemia in childhood is accompanied by paradoxically low serum growth hormone and appropriate cortisol counterregulatory hormonal responses. J. Clin. Endocrinol. Metab. 2003, 88, 3715-3723. [CrossRef]

88. Tennese, A.A.; Wevrick, R. Impaired hypothalamic regulation of endocrine function and delayed counterregulatory response to hypoglycemia in Magel2-null mice. Endocrinology 2011, 152, 967-978. [CrossRef]

89. Zhao, T.J.; Liang, G.; Li, R.L.; Xie, X.; Sleeman, M.W.; Murphy, A.J.; Valenzuela, D.M.; Yancopoulos, G.D.; Goldstein, J.L.; Brown, M.S. Ghrelin o-acyltransferase (GOAT) is essential for growth hormone-mediated survival of calorie-restricted mice. Proc. Natl. Acad. Sci. USA 2010, 107, 7467-7472. [CrossRef]

90. Dhillon, H.; Zigman, J.M.; Ye, C.; Lee, C.E.; McGovern, R.A.; Tang, V.; Kenny, C.D.; Christiansen, L.M.; White, R.D.; Edelstein, E.A.; et al. Leptin directly activates SF1 neurons in the VMH, and this action by leptin is required for normal body-weight homeostasis. Neuron 2006, 49, 191-203. [CrossRef]

91. Pedroso, J.A.; Silveira, M.A.; Lima, L.B.; Furigo, I.C.; Zampieri, T.T.; Ramos-Lobo, A.M.; Buonfiglio, D.C.; Teixeira, P.D.; Frazao, R.; Donato, J., Jr. Changes in leptin signaling by SOCS3 modulate fasting-induced hyperphagia and weight regain in mice. Endocrinology 2016, 157, 3901-3914. [CrossRef] [PubMed]

92. Furigo, I.C.; Teixeira, P.D.; Quaresma, P.G.F.; Mansano, N.S.; Frazao, R.; Donato, J. STAT5 ablation in AgRP neurons increases female adiposity and blunts food restriction adaptations. J. Mol. Endocrinol. 2020, 64, 13-27. [CrossRef] [PubMed] 
93. Li, R.L.; Sherbet, D.P.; Elsbernd, B.L.; Goldstein, J.L.; Brown, M.S.; Zhao, T.J. Profound hypoglycemia in starved, ghrelin-deficient mice is caused by decreased gluconeogenesis and reversed by lactate or fatty acids. J. Biol. Chem. 2012, 287, 17942-17950. [CrossRef] [PubMed]

94. McFarlane, M.R.; Brown, M.S.; Goldstein, J.L.; Zhao, T.J. Induced ablation of ghrelin cells in adult mice does not decrease food intake, body weight, or response to high-fat diet. Cell Metab. 2014, 20, 54-60. [CrossRef] [PubMed]

95. Fujikawa, T.; Castorena, C.M.; Pearson, M.; Kusminski, C.M.; Ahmed, N.; Battiprolu, P.K.; Kim, K.W.; Lee, S.; Hill, J.A.; Scherer, P.E.; et al. SF-1 expression in the hypothalamus is required for beneficial metabolic effects of exercise. eLife 2016, 5, e18206. [CrossRef]

96. Pedroso, J.A.B.; de Mendonca, P.O.R.; Fortes, M.A.S.; Tomaz, I.; Pecorali, V.L.; Auricino, T.B.; Costa, I.C.; Lima, L.B.; Furigo, I.C.; Bueno, D.N.; et al. SOCS3 expression in SF1 cells regulates adrenal differentiation and exercise performance. J. Endocrinol 2017, 235, 207-222. [CrossRef]

97. Pedroso, J.A.B.; Ramos-Lobo, A.M.; Donato, J., Jr. SOCS3 as a future target to treat metabolic disorders. Hormones (Athens) 2019, 18, 127-136. [CrossRef]

98. Andreoli, M.F.; Donato, J.; Cakir, I.; Perello, M. Leptin resensitisation: A reversion of leptin-resistant states. J. Endocrinol. 2019, 241, R81-R96. [CrossRef]

99. Pedroso, J.A.B.; Dos Santos, L.B.P.; Furigo, I.C.; Spagnol, A.R.; Wasinski, F.; List, E.O.; Kopchick, J.J.; Donato, J., Jr. Deletion of growth hormone receptor in hypothalamic neurons affects the adaptation capacity to aerobic exercise. Peptides 2021, 135, 170426. [CrossRef]

100. Wasinski, F.; Furigo, I.C.; Teixeira, P.D.S.; Ramos-Lobo, A.M.; Peroni, C.N.; Bartolini, P.; List, E.O.; Kopchick, J.J.; Donato, J., Jr. Growth hormone receptor deletion reduces the density of axonal projections from hypothalamic arcuate nucleus neurons. Neuroscience 2020, 434, 136-147. [CrossRef]

101. Sadagurski, M.; Landeryou, T.; Cady, G.; Kopchick, J.J.; List, E.O.; Berryman, D.E.; Bartke, A.; Miller, R.A. Growth hormone modulates hypothalamic inflammation in long-lived pituitary dwarf mice. Aging Cell 2015, 14, 1045-1054. [CrossRef] [PubMed]

102. Bouret, S.G.; Draper, S.J.; Simerly, R.B. Trophic action of leptin on hypothalamic neurons that regulate feeding. Science 2004, 304, 108-110. [CrossRef] [PubMed]

103. Ramos-Lobo, A.M.; Teixeira, P.D.; Furigo, I.C.; Melo, H.M.; e Silva, N.D.M.L.; De Felice, F.G.; Donato, J., Jr. Long-term consequences of the absence of leptin signaling in early life. eLife 2019, 8, e40970. [CrossRef] [PubMed]

104. Quaresma, P.G.F.; Dos Santos, W.O.; Wasinski, F.; Metzger, M.; Donato, J., Jr. Neurochemical phenotype of growth hormoneresponsive cells in the mouse paraventricular nucleus of the hypothalamus. J. Comp. Neurol. 2021. [CrossRef]

105. Simmons, D.M.; Swanson, L.W. Comparison of the spatial distribution of seven types of neuroendocrine neurons in the rat paraventricular nucleus: Toward a global 3D model. J. Comp. Neurol. 2009, 516, 423-441. [CrossRef]

106. Bohlen, T.M.; Zampieri, T.T.; Furigo, I.C.; Teixeira, P.D.; List, E.O.; Kopchick, J.; Donato, J., Jr.; Frazao, R. Central growth hormone signaling is not required for the timing of puberty. J. Endocrinol. 2019, 243, 161-173. [CrossRef] [PubMed]

107. Schwarz, L.A.; Luo, L. Organization of the locus coeruleus-norepinephrine system. Curr. Biol. 2015, 25, R1051-R1056. [CrossRef]

108. Cruzat, V.F.; Donato, J., Jr.; Tirapegui, J.; Schneider, C.D. Growth hormone and physical exercise: Current considerations. Rev. Bras. Cienc. Farm. 2008, 44, 549-562. [CrossRef]

109. Amiel, S.A.; Sherwin, R.S.; Simonson, D.C.; Lauritano, A.A.; Tamborlane, W.V. Impaired insulin action in puberty. A contributing factor to poor glycemic control in adolescents with diabetes. N. Engl. J. Med. 1986, 315, 215-219. [CrossRef] 